\title{
ZSVTS and its Action in the Preparation of Euroengineers Slovakia
}

\author{
Dušan Petráš, Jozef Krajčovič \\ Association of Slovak Scientific and Technological Societies, Bratislava, Slovak Republic
}

\begin{abstract}
The special mission of the Association of Slovak Scientific and Technological Societies (ZSVTS), such a association of interest professional scientific and technological societies and associations, is helping to raise the level of science and technology in the Slovak Republic, the development of education and of international cooperation in the field of science and technology, promoting solutions to tasks within the national technological policy. The activities of the ZSVTS are significantly documented by the amount of professional and educational events that members of the ZSVTS carried out annually, ZSVTS experts and other professionals in a variety of commissions, projects, and committees, not least by the promotion of new knowledge, highlighting the personalities of science and technology and their creative work. The activity of ZSVTS in the preparation and getting of Slovak euroingineers is very important. ZSVTS represents a Slovak Republic in an important engineering federation-FEANI (Fédération Européenne d'Associations Nationales d'Ingénieurs), which refers to the Federation of the European national associations of engineers. Membership in this federation provides Slovak technical engineers the possibility to get the certificate of European engineer-EUR ING, which is accepted in Europe and in overseas. EUR ING certificate confirms their educational, professional, and ethical quality. This fact contributes to the achievement of an adequate position in both domestic and foreign organizations. The fact that our expert receives the euring title is committed to continuous learning and increasing his/her personal professionalism. The most successful and prosperous foreign companies perceive our euroengineers from the perspective of their professional and human qualities, and also of their skills to continually educate. The most important in this paper ZSVTS activities in the preparation of and getting the new euroinžinierov of the Slovak Republic are described.
\end{abstract}

Keywords: European engineer, FEANI, ZSVTS, EUR ING

\section{Introduction}

The Association of Slovak Scientific and Technological Societies (abbr. ZSVTS or Union) is a voluntary, non-profit, democratic, and non-political association of professional interest specialized and technological societies, committees, unions, regional coordination centres, and other separate legal persons. It was established on the Slovak congress of the former Czechoslovak scientific and technical society in March 17, 1990 and has its residence in Bratislava, Slovakia. The professional mission of the Association is to assist in raising the level of

Dušan Petráš, professor, Ph.D., EUR ING, Association of Slovak Scientific and Technological Societies. Jozef Krajčovič, Ph.D., EUR ING, Association of Slovak Scientific and Technological Societies. 
professional science and technology in the Slovak Republic, the development of education and of international cooperation in the field of science and technology, the solution of tasks in the framework of the national technological policy. ZSVTS as the only organization in Slovakia has the authority to assess and recommend candidates for approval of a major title - the European engineer-EUR ING. This title gives an advantage for engineer position in the labour market favours both at home and abroad; it is the guarantee of a professional engineering quality.

\section{Actual ZSVTS Priorities}

Currently among the main priorities of the ZSVTS are:

- Highlighting the position of the ZSVTS as the representative of the scientific and technical community so in Slovakia as well as abroad;

- The promotion of co-optation of ZSVTS experts to advisory committees and commissions at ministries, employers' unions and associations, scientific councils of universities, professional chambers, business associations, as well as in the Slovak Academy of Sciences;

- Increase in the popularisation of ZSVTS and its members in the media, in particular through the cycle of sessions that inform how involved the members of the ZSVTS for the exceptional results of the applied research and development;

- Creating conditions for an increase in the influence of the ZSVTS, including the wider development of its club activities in all regions of the Slovak Republic;

- Promoting the social assessment of the creative work of scientists and technicians, actively contributing to the protection of intellectual property rights, the results of the work of individuals and research teams;

- Support for the development of knowledge and skills of youth, their involvement in professional competitions, and the initiation of the entry of young people into the activities of the ZSVTS;

- Improving information of Slovak technical community about the present and the perspectives for the development of science and technology.

\section{The Main Field of ZSVTS Operation}

The Union of its mission, visible to the public, meets the activities, which fall mainly into three main activities of its focus, and those are: science and technology, education, and international activities.

In the field of science and technology ZSVTS aims to:

- Prepare the program ZSVTS in the popularisation of science and technology in a society with the aim of increasing public awareness of the role of science and technology in society in everyday life;

- Promote and increase the interest of young people in science, technology, and scientific careers career researcher;

- Promote the participation of the public interest in science and technology and the transfer of expertise to society through intensive dialogue;

- Cooperate with Ministry of Education, Science, Research and Sport of the Slovak Republic in the area of science and technology popularisation;

- Cooperate with the Slovak Research and Development Agency with a view to promoting human potential in the field of research and development and popularisation of science in society. 
In the field of education ZSVTS wants to:

- Promote training activities aimed at the development of the personality and quality of life and achieve the necessary qualifications;

- Focus on the promotion of lifelong education, training, and the promotion of education to improve the quality of life;

- Cooperate with Ministry of Education, Science, Research and Sport of the Slovak Republic, with the National Qualifications Framework and with the Association of Adult Education Institutions in the Slovak Republic in the implementation of the project of lifelong learning and the building up of advisory centres.

ZSVTS in the field of international activities:

- Continues in the active membership in WFEO (World Federation of Engineering Organizations) and the FEANI (European Federation of National Engineering Associations);

- Looks for support for the participation of the ZSVTS member organizations in the international structures;

- Supports the active participation of its members in the world's major engineering events;

- Organizes thematic business trips to important trade fairs and exhibitions in the field of science and technology;

- Supports ZSVTS experts at their engagement in the creation of documents and directives of the EU;

- Actively promotes Slovak National Committee for FEANI in the area of issuing the certificate of the European engineer-EUR ING and professional card of the engineers;

- Supports Club of euroengineers of Slovakia at its specialized, educational, and information activities.

\section{Euroengineers Abroad and in the Slovak Republic}

What does it means the title euroinžinier-ING ING and what is its meaning for the holder and for employers? The title EUR ING certifies that its holder is a graduate of the Technical University, has the title of "engineer", has the professional experience, and speaks one of the world's languages. It is a guarantee of professional engineering as quality for domestic and foreign companies. For the individual, it comes on the official objective confirmation of its education, professionalism, and moral characteristics. For the employer, it is quality mark of enterprise and its ability to handle the rigors of technological processes in production, apply on the market, and so on. If in the company they are working people with education, which has international certificate, it is for a foreign partner, convincing proof and a guarantee of professional engineering quality and challenging professional background organization. It is especially important for enterprises to have or want to achieve close cooperation with foreign partners if it has a euroengineer in its staff. This is confirmed by the fact that, according to the statistics, in Europe there is currently more than FEANI 33 thousand euroengineers, and that the holders of this certificate are primarily engineers from developed Western European countries. Even States that are comparable with the Slovak population (Switzerland, Finland, the Netherlands, Hungary, Greece, Norway, and Sweden), are interested in a diploma referred to significant. Prestige of EUR ING title is also confirmed by the fact that its holders are presidents and expresidents of the European and World Federation of engineers and other organizations. The number of euroengineers is a professional "business card" of the country. 


\section{Where to Slovak Technical Engineer Earns About EUR ING Title and What Steps Must Be Performed by the Candidate for the Title EUR ING in Slovakia?}

Information about EUR ING provides official FEANI website (www.feani.org), ZSVTS website (www.zsvts.sk), and the website www.euring.sk. Additional and more detailed information is available to Slovak Monitoring Committee for FEANI (SMKF) based in Bratislava in the Association of Slovak Scientific and Technological Societies by telephone (on the number ++ 42125020 7629, 49), or in personal contact at ZSVTS, Kocel'ova 15, Bratislava. If the applicant complies with the conditions laid down by the SMKF and is interested in getting a EUR ING certificate addresses its request (to SMKF address) to obtain a certificate, together with the completed questionnaire (in the prescribe FEANI language mutation) and other documents, which are: a copy of the certificate from middle school, a copy of a diploma obtained in an accredited engineering at Technical University certified notary document confirming that the applicant has pursued the practice in his field for at least two years the language test of English, French or German language, a brief curriculum vitae with the characteristics of the professional activities of the applicant in English and in one of the languages laid down by FEANI-an overview of the engineering practice of the applicant (in foreign language) from the end of the school to the present day. The application shall be paid a registration fee in the amount of eur 400.00 , which is the cost of implementing the administrative and organizational process of obtaining coverage.

\section{Which Slovak Technical Universities Have Their Faculties of Accredited as Required by FEANI?}

European Monitoring Committee FEANI on the basis of the report of the Working group FEANI ranked 22 faculties of the Slovak technical universities to the FEANI INDEX, i.e., in the list of schools equivalent to FEANI level training to obtain a certificate, EUR ING exacting specifications. It is about the following faculties:

(1) Slovak Technical University in Bratislava:

Faculty of Mechanical Engineering, Faculty of Civil Engineering, Faculty of Electrical Engineering and Information Technology, Faculty of Chemical and Food Technology, Faculty of Material Science and Technology in Trnava.

(2) Technical University in Košice:

Faculty of Mining, Ecology, Process Control and Geotechnology, Faculty of Mechanical Engineering, Faculty of Electrical Enginerering and Informatics, Faculty of Metallurgy, Faculty of Civil Engineering, Faculty of Aeronautics, Faculty of Manufacturing Technologies in Prešov.

(3) University of Žilina in Žilina:

Faculty of Operation and Economics of Transport and Communications, Faculty of Mechanical Engineering, Faculty of Civil Engineering, Faculty of Electrical Engineering, Faculty of Management Science and Informatics.

(4) Technical University in Zvolen:

Faculty of Forestry, Faculty of Wood Sciences and Technology, Faculty of Ecology and Environmental Sciences.

(5) Alexander Dubček University of Trenčín:

Faculty of Special Techniques, Faculty of Industrial Technologies in Púchov. 


\section{Mission and Main Activities of the ZSVTS in the Preparation of and Support the Future of Slovak Euroengineers}

The basic assumption is a membership of ZSVTS in the FEANI; that is, Slovak Republic by means ZSVTS is a member state of European federation of national engineering associations (FEANI). ZSVTS has set up a national representative of the FEANI in Slovakia—Slovak National Committee for FEANI—SNKF.

SNKF has the following missions:

- Ensures the representation ZSVTS in FEANI, fulfills the tasks connected with membership ZSVTS in FEANI;

- Contributes to the recognition of academic titles of Slovak technical engineers and supports them in terms of the performance of a profession abroad;

- Protects and promotes the professional interests of engineers;

- Supports the engineering education and professional experience;

- Supports professional and cultural mutual contacts with engineers within the Europe;

- Initiates the inclusion of the Slovak faculties preparing engineers to FEANI Index;

- Makes an effort for the inclusion of the Slovak engineers, who have expressed an interest and comply with the requirements laid down in the register of the FEANI.

The SNKF members are representatives of the ZSVTS, academic Slovak technical universities, representatives of research institutions and leading Slovak academy of sciences, the central authorities of the State administration of the Slovak Republic, major enterprises and civil associations and chambers of commerce. The President, the Vice-President, and the Secretary General of the SNKF are the representatives of the ZSVTS.

\section{The Activities of the Slovak National Committee for FEANI}

Slovak National Committee for FEANI:

- Maintains the official contacts with the FEANI authorities;

- Represents of ZSVTS in FEANI as a representative of the Slovak Republic;

- Intermediates the information about conditions to obtain the EUR ING certificate (even the title) for professional public of Slovak Republic;

- Ensures, in cooperation with the Slovak Monitoring Committee for FEANI, selection, evaluation, and proposals of candidates from Slovak Republic for EUR ING certificate;

- Prepares for the European Monitoring Committee for FEANI written materials relating to the system of education of engineers, and the acquisition of academic titles in the Slovak technical universities, including applicable legislation in this area;

- Collects information about lifelong learning of engineers in the Slovak Republic and verifies its compatibility with European standards;

- Cooperates with the European Monitoring Committee for FEANI for the accreditation of faculties of Slovak technical universities according to the terms of the FEANI. 


\section{The Current Activities of the ZSVTS in the Preparation of Euroengineers}

ZSVTS in the rest of the period was prepared by a broad campaign to get more people interested in EUR ING title, which is the main instrument for the mobility of these professionals, confirming their professional qualities in obtaining suitable employment in high-tech companies and organizations in Slovakia as well as abroad.

ZSVTS initiated the foundation of the Club euroengineers of Slovakia as a grouping bringing together experts in selected technical areas such as: mining, transport and communications, timbering, electrical engineering, metallurgy, ecology and environmental, chemical technology, forestry, materials technology, management and computer science, construction, mechanical engineering, aviation, production technologies, special equipment, industrial technologies. ZSVTS provides spaces and opportunities for engaging these experts and helps in the implementation of some of the activities of the Club.

ZSVTS by means the members of SNKF - prorectors of the Slovak technical universities strengthens the promotion of vocational training and orientation of students in their education in study programs accredited in FEANI.

ZSVTS activity is expressed by editing of promotional materials and articles in both print and electronic media; presentations, interviews, interview representatives of the ZSVTS and SNKF on various forums and events. As a result of these efforts is the growing interest in the study of engineering and science programs at Slovak universities, interest in obtaining EUR ING certificate, as well as support for further education and awareness of professionalism of our experts.

\section{Conclusion}

The preparation of the euroengineers has its importance in several respects; whether from the perspective of our experts in obtaining favourable opportunities for jobs, or from the perspective of the employer-have guaranteed experts in your organization (which increases the chances of getting a variety of contracts and projects), but also from the international perception of Slovakia as the country where they are established, high-level officials and the people to the ethic and social level. Slovakia currently has a large number of professionals who meet the criteria for obtaining the title EUR ING (Slovak Republic has around 125 euroengineers). It is, therefore, to all interested entities of our state in order to assist in the promotion of the issue of certificates, the other faculties of the Slovak technical universities evaluation to FEANI INDEX, and the extension of the base holders of the prestigious title of the EUR ING.

\section{References}

Driensky, D., \& Krajčovič J. (2012). Certifikát európskeho inžiniera (Certificate of the European engineer) (p. 5). Spektrum STU, ISSN 1336-2593.

Krajčovič, J. (2011a). Európsky trh chce európskych inžinierov (European market wants European engineers) (pp. 8-9). Quark, ISSN 1335-4000.

Krajčovič, J. (2011b). Naše technické školstvo má uznanie medzinárodných inštitúcií (Our technical education has the recognition of international institutions). $\quad \mathrm{HN} \quad$ online. Retrieved from http://dennik.hnonline.sk/slovensko/405680-nase-technicke-skolstvo-ma-uznanie-medzinarodnych-institucii Krajčovič, J. (2013a). 25 rokov technickej diplomacie (25 years of technological diplomacy). ZSVTS, ISBN 978-80-971926-0-0. 
Krajčovič, J. (2013b). Európsky priestor potrebuje euroinžinierov (European space needs euroengineers) (pp. 30-31). Transport a logistika, ISSN 1337-8813.

Šimončič, L., Krajčovič, J., \& Vincencová, J. (2000). Európsky inžinier (European engineer). EUR ING, ZSVTS, ISBN 80-233-0453-4. 